\title{
Chironomids (Diptera: Chironomidae) in Lakes of Central Yakutia and Their Indicative Potential for Paleoclimatic Research
}

\author{
L. B. Nazarova ${ }^{a, b}$, L. A. Pestryakova ${ }^{c}$, L. A. Ushnitskaya ${ }^{d}$, and H.-W. Hubberten ${ }^{d}$ \\ ${ }^{a}$ Alfred Wegener Institute for Polar and Marine Research, Research Unit Potsdam, \\ Telegrafenberg A43, Potsdam, 14473 Germany \\ E-mail: nazarova larisa@mail.ru \\ ${ }^{b}$ Kazan' State University, ul. Kremlyovskaya 18, Kazan', 420008 Russia \\ ${ }^{c}$ Yakutian State University, ul. Belinskogo 58, Yakutsk, 677891 Russia \\ ${ }^{d}$ Institute of Applied Ecology of North of the Academy of Sciences of the Republic of Sakha (Yakutia), \\ pr. Lenina 35, Yakutsk, 677007 Russia
}

\begin{abstract}
A study of chironomid fauna was carried out in two regions of central Yakutia. Fossilized remnants of head capsules were sampled from shallow layers of the bottom sediments of lakes. Seventy five taxa of chironomids have been determined. Statistical analysis shows that the spatial distribution of chironomid taxa in the study regions is mainly controlled by ions of aluminium and magnesium, mean July temperature, transparency and content of oxygen in water. The obtained results serve as the base for development of a chironomid temperature model used for reconstruction of Holocene and Pleistocene paleotemperatures of the Russian North.
\end{abstract}

DOI: $10.1134 / \mathrm{S} 1995425508030089$

Chironomids (Insecta: Diptera) belong to the most abundant group of fresh-water bottom-dwelling macroinvertebrates. Because of their short life cycle, chironomids quickly adapt to environmental changes and, therefore, are useful indicators of various environmental impacts on fresh water, including effects of eutrophication, acidification, toxic pollution, and other chemical and physical disturbances $[1,2]$.

Larval head capsules of chironomids preserved in lake sediment as subfossils (Fig. 1) are abundant and identifiable [3-6]. In global scale the distribution and abundance of chironomids are mostly limited by temperature [7-11]. It makes them one of the best quantitative indicators of the climate change [12-16]. Chironomid-based temperature models have been successfully developed in Western Europe and North America [17-19]. They can be used for precise paleotemperature reconstructions [see review in 4, 20]. However, outside the regions for which they have been developed these models are of limited application. The models developed in northwestern Europe do not cover a temperature gradient long enough for them to be used in regions of extreme continental climate like East Siberia and Russian Arctic. No temperature model based on chironomids has been developed for northern Russia yet. Our investigation is aimed at studying subfossil chironomid fauna of central Yakutian lakes and quantifying the relationship between chironomid taxa assemblages and their environment in order to estimate the potential of chironomids for quantitative paleoenvironmental reconstructions in the Russian north.

\section{MATERIAL AND METHODS}

The Republic of Sakha (Yakutia) is located in the northeastern part of Russia (between $55^{\circ} 29^{\prime}$ and $76^{\circ} 46^{\prime} \mathrm{N}$ and $105^{\circ} 32^{\prime}$ and $162^{\circ} 55^{\prime} \mathrm{E}$; Fig. 2). It spreads over $2500 \mathrm{~km}$ from east to west and $2000 \mathrm{~km}$ from north to south. Yakutia includes different geographical zones: tundra at the Arctic Ocean coast, mountains in the east and south of Yakutia (up to 2000-3000 m asl) and taiga forests in the west [21]. Nearly the whole territory is covered by permafrost [22]. Yakutia is a region with an extreme continental climate characterized by pronounced seasonal gradients. The coldest month is January with average temperature below $-40{ }^{\circ} \mathrm{C}$, and the lowest temperatures down to $-71.2^{\circ} \mathrm{C}$. Average July temperature varies from $+2 \ldots+4{ }^{\circ} \mathrm{C}$ in the Laptev Sea islands to $+18 \ldots+19{ }^{\circ} \mathrm{C}$ in central Yakutia near Yakutsk with the maximum summer temperatures of 38 to $40{ }^{\circ} \mathrm{C}$. Annual temperatures average -10 to $-12{ }^{\circ} \mathrm{C}$. The annual precipitation is 250 to $300 \mathrm{~mm}$, which is inferior to the annual evaporation $(350-400 \mathrm{~mm})$ [23]. The driest area is the Central Yakutian lowland [24, 25]. In summer, evaporation is four times higher than precipitation.

There are many lakes in Yakutia, which are mostly originated by thermokarst processes. They are rather shallow $(1-3 \mathrm{~m})$ and are characterized by specific thermal and chemical regimes, making them sensitive to recent climate changes [26].

During the summers of 2003 and 2004, a total of 38 lakes were sampled in two regions of central Yakutia (Fig. 2): 25 lakes were sampled near Vilyuisk (V), and 

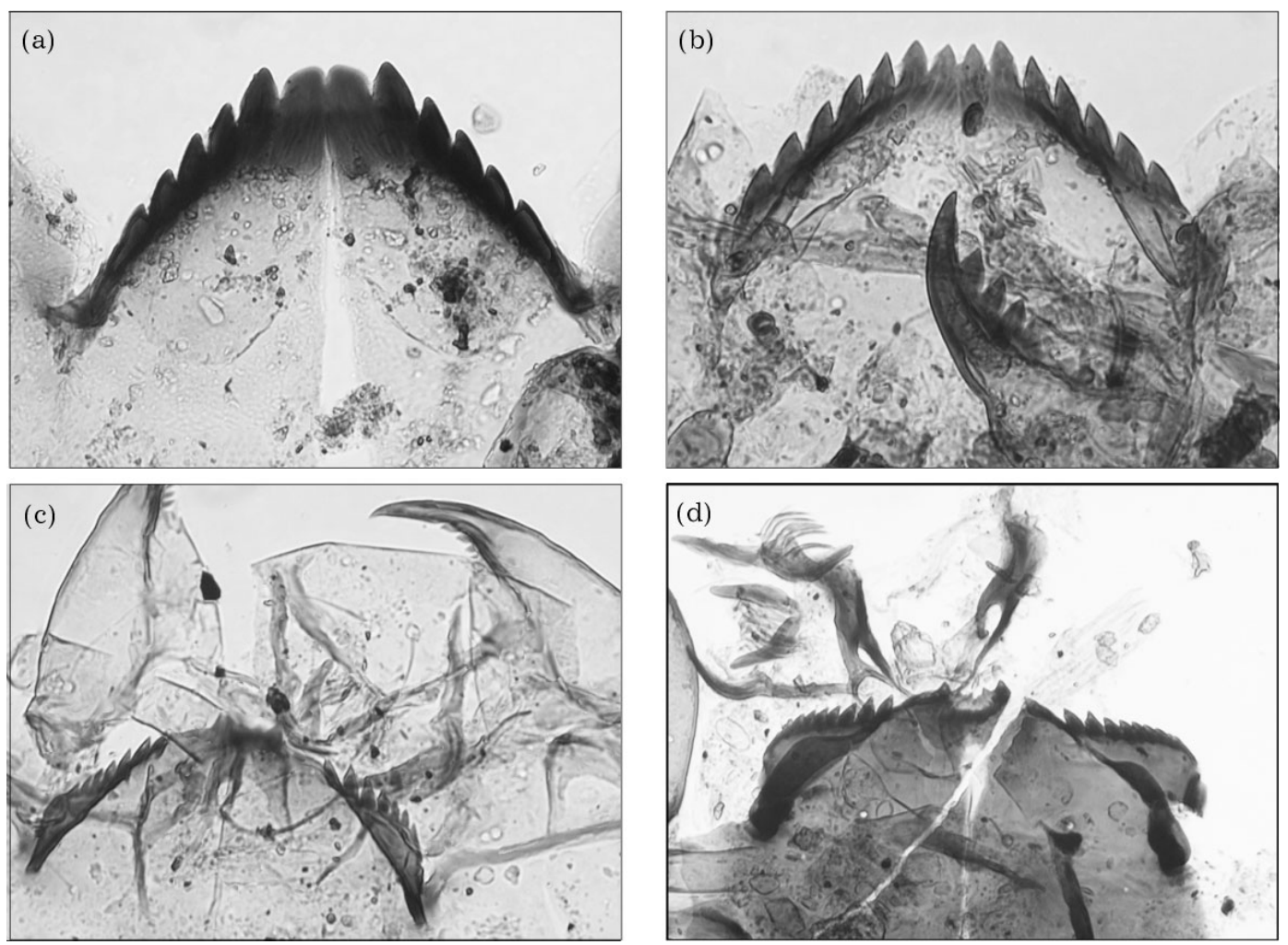

Fig. 1. Chironomid head capsules (Photo Nazarova L.B.). (a) Prectrocladius barbimanus, (b) Trissocladius, (c) Propsilocerus lacustris, (d) P. jacuticus.

13 lakes, near Yakutsk (Y). The two study areas are underlain by continuous permafrost, within the boreal coniferous forest zone. The vegetation is dominated by taiga trees such as larch (Larix dahurica), pine (Pinus sylvestris), and birch (Betula pendula). From each lake, we took water samples, surface sediment samples, phytoplankton and periphyton samples as well as short lake sediment cores. Chemical analyses encompassed about 20 parameters and proved that the study area was not affected by any sort of anthropogenic influence [27, 28]. All lakes are slightly alkaline, oxygen-rich, have moderate transparency and mostly high ionic concentrations. Mean July, mean January and mean annual temperatures used in our analyses were calculated from the Gridded climate data [29], measured $2 \mathrm{~m}$ above the ground in standard meteorological screens. Using these data, we estimated the mean air temperature at each lake by spatial interpolation of elevation and distance from the coast. According to the calculation, the lakes are within a temperature range for mean July temperature: from +16.52 to $+18.12{ }^{\circ} \mathrm{C}$, for mean January temperature: from -37.88 to $-43.46^{\circ} \mathrm{C}$, and mean annual temperature: from -8.27 to $-10.23^{\circ} \mathrm{C}$. Selected temperature ranges, although rather narrow, reflect the real temperature variability in this region. For more details about sampling sites and lake features see Kumke et al., 2006 [27].
Sediment samples for chironomid analysis were treated by standard techniques described by Brooks and Birks [13]. Subsamples of wet sediments were deflocculated in a $10 \% \mathrm{KOH}$ solution, heated to $70{ }^{\circ} \mathrm{C}$ for 10 minutes, to which boiling water was added and left to stay for 20 minutes. The sediment suspension was successively passed through $125 \mu \mathrm{m}$ and $95 \mu \mathrm{m}$ sieves. Chironomid larval head capsules numbered 47 to 292 per sample were picked out of a grooved Bogorov sorting tray using fine forceps under a stereomicroscope $(\times 25-\times 40)$. Larval head capsules are mounted two at a time in Euparal, ventral side up, under a cover slip 6 $\mathrm{mm}$ in diameter, with ten cover slips per microscope slide. A total of 3434 chironomid head capsules were mounted and identified. Chironomids were identified with reference to [30-34] and the national Chironomidae collection at the Natural History Museum, London, UK.

Because of the known difficulties in distinguishing the head capsules of fossilized chironomids [4, 5, 33], they were identified to the level of genus or a certain morphotype presently adopted (e.g., Psectrocladius psilopterus type, $P$. sordidellus type, P. barbimanus type) called hereinafter taxon.

As the soft parts of larvae of the genus Chironomus very important for species identification are not preserved in bottom sediments, their head capsules are subdivided into two morphotypes officially adopted in 


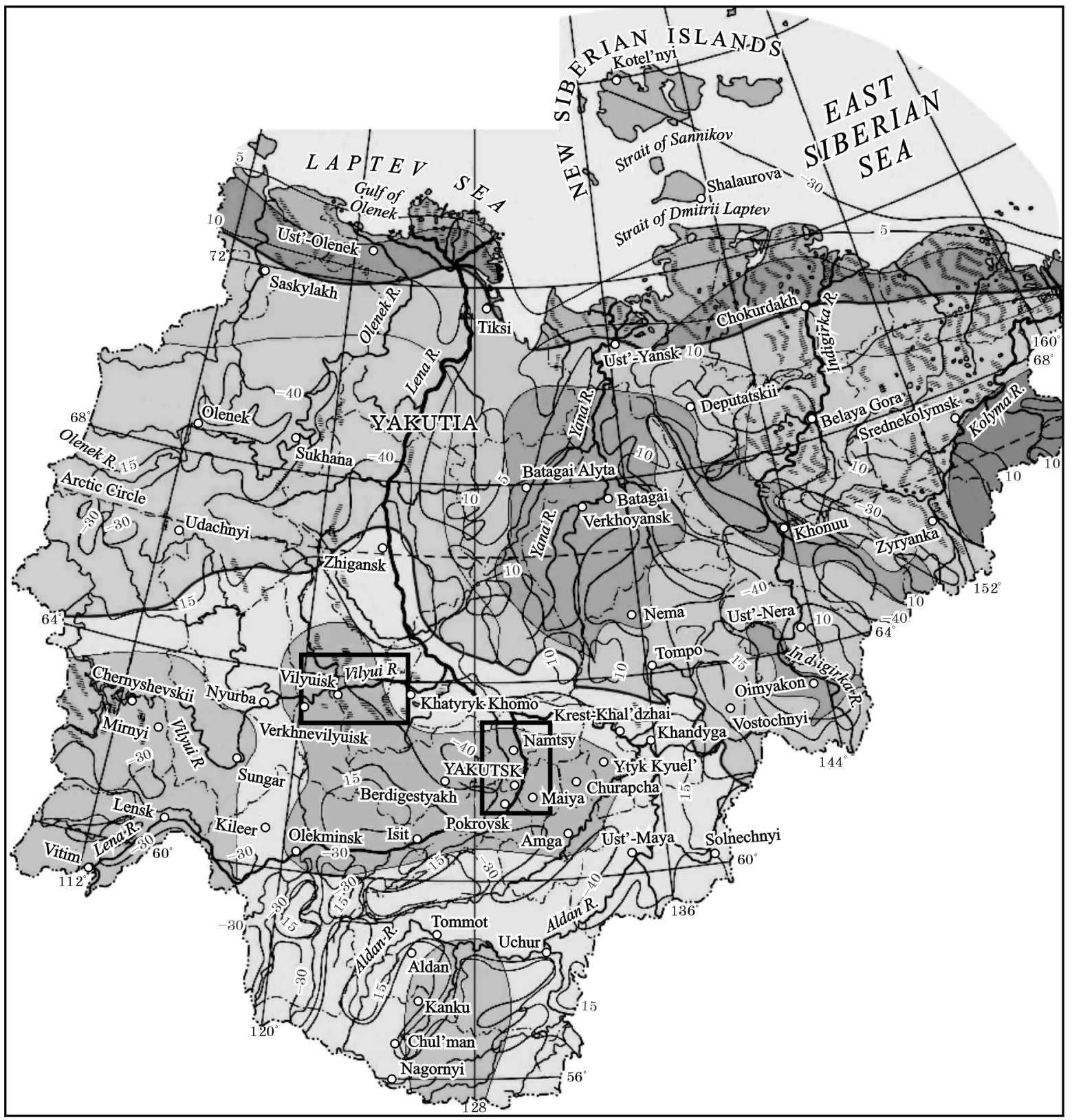

Fig. 2. Regions of investigation.

paleolimnology. These two morphotypes are distinguished in fossilized chironomids by the number of teeth on the mandible and by the ratio of heights of mentum's teeth [34]: Chironomus anthracinus type and Chironimus plumosus type. Given no mandible, the specimen was identified to the level of genus.

In the subfamily Tanypodinae one taxon, Procladius, was identified, and the rest remained unidentified (Tanypodinae unindef.) because of a great deal of controversies. Unfortunately, the identification of the subfamily Tanypodinae is quite a challenge. The remains of head capsules are often lacking even mandibles and ligula, to say nothing of paraligulas. Therefore, identifi- cation is made by the position of the pores on the ventral and dorsal sides of the head capsule [34], which is often impossible if the head capsules are ill-preserved or contain even a minor impurity. Moreover, the location of the pores varies depending on the age and individual characteristics of the larvae. The frequency of occurrence of Tanypodinae in bottom sediments of the lakes of central Yakutia did not exceed $4.88 \%$, averaging $2.27 \%$. The full identification of the subfamily Tanypodinae will be made after comparative analysis of the material from all lakes that will be included into the temperature model. At present, 235 lakes have been sampled. 
Table 1. Statistical summary of the limnological measurements of the study lakes in central Yakutia

\begin{tabular}{lcccccc}
\hline \multicolumn{1}{c}{ Variable } & Min & Max & Mean & Median & SD & Skew \\
\hline$T_{\text {air July }}\left({ }^{\circ} \mathrm{C}\right)$ & 16.52 & 18.12 & 17.30 & 17.18 & 0.49 & 0.27 \\
$T_{\text {air January }}\left({ }^{\circ} \mathrm{C}\right)$ & -43.46 & -37.88 & -39.85 & -39.21 & 1.64 & -0.63 \\
$T_{\text {air annual }}\left({ }^{\circ} \mathrm{C}\right)$ & -10.23 & -8.27 & -9.07 & -8.86 & 0.58 & -0.38 \\
$T_{\text {water }}\left({ }^{\circ} \mathrm{C}\right)$ & 16.8 & 31.4 & 22.65 & 21.65 & 3.27 & 0.72 \\
$Z_{\text {water }}(\mathrm{m})$ & $0-7$ & 17.1 & 2.38 & 1.80 & 2.65 & 4.88 \\
$Z_{\text {Secchi }}(\mathrm{m})$ & 0.18 & 3.2 & 0.95 & 0.74 & 0.69 & 1.49 \\
$\mathrm{Conductivity}(\mu \mathrm{S} / \mathrm{cm})$ & 70 & 2980 & 397.59 & 273.50 & 532.34 & 3.80 \\
$\mathrm{pH}$ & 7.70 & 9.92 & 8.51 & 8.52 & 0.54 & 0.54 \\
$\mathrm{O}_{2}(\mathrm{mg} / \mathrm{l})$ & 2.5 & 38.3 & 12.48 & 8.85 & 9.27 & 1.15 \\
$\left.\mathrm{DOC}^{-} \mathrm{mg} / \mathrm{l}\right)$ & 0 & 43.85 & 19.27 & 17.38 & 12.21 & 0.34 \\
$\mathrm{Cl}^{-1}(\mathrm{mg} / \mathrm{l})$ & 0.30 & 209.00 & 12.37 & 2.48 & 35.45 & 5.01 \\
$\mathrm{SO}_{4}^{-}(\mathrm{mg} / \mathrm{l})$ & 0.10 & 9.57 & 1.84 & 1.47 & 2.15 & 2.42 \\
$\mathrm{NO}-(\mu \mathrm{g} / \mathrm{l})$ & 0.10 & 32.24 & 2.39 & 0.12 & 6.84 & 4.14 \\
$\mathrm{NH}_{4}^{+}(\mu \mathrm{g} / \mathrm{l})$ & 60 & 620 & 209.10 & 160.00 & 168.7 & 1.5 \\
$\mathrm{NO}_{2}^{-}(\mu \mathrm{g} / \mathrm{l})$ & 3.5 & 1200 & 96.90 & 7.80 & 267.7 & 3.4 \\
$\mathrm{PO}_{4}^{3-}(\mathrm{mg} / \mathrm{l})$ & 0.1 & 0.92 & 0.51 & 0.51 & 0.58 & 5.2 \\
$\mathrm{Al}(\mu \mathrm{g} / \mathrm{l})$ & 20.0 & 86.2 & 33.49 & 26.90 & 16.07 & 1.84 \\
$\mathrm{Ca}(\mathrm{mg} / \mathrm{l})$ & 0.53 & 38.50 & 18.25 & 16.95 & 9.49 & 0.16 \\
$\mathrm{Fe}(\mu \mathrm{g} / \mathrm{l})$ & 22.5 & 354 & 94.12 & 73.40 & 72.84 & 2.04 \\
$\mathrm{Mg}(\mathrm{mg} / \mathrm{l})$ & 0.29 & 210 & 30.53 & 13.75 & 53.14 & 2.92 \\
$\mathrm{Na}(\mathrm{mg} / \mathrm{l})$ & 0.52 & 578 & 38.31 & 11.20 & 100.46 & 4.64 \\
$\mathrm{Si}(\mathrm{mg} / \mathrm{l})$ & 0.21 & 23.2 & 4.95 & 2.49 & 5.98 & 1.63 \\
\hline
\end{tabular}

Note: SD means standard deviation, Skew - asymmetry, $Z_{\text {water }}-$ maximal depth of lake, $Z_{\text {Sechi }}-$ Secchi depth.

Only chironomid taxa occurring in at least 2 lakes with a relative abundance of at least $2 \%$ or more in at least one sample were included into the statistical analysis. According to this criterion, of a total of 75 chironomid taxa only 47 were used for analyzing the data. Detrended correspondence analysis (DCA) was applied to the chironomid data to calculate the length of sampled environmental gradients. This is necessary to make a choice between unimodal or linear numerical techniques for modelling the relationship between the chironomid assemblages and environmental variables [35]. DCA assumes that species respond in a unimodal manner along hypothetical environmental gradients [36-38]. The DCA (square root transformation of species data, rare taxa downweighted, detrended by segments) revealed a gradient length of axis 1 of $1.85 \mathrm{SD}$ units, suggesting that linear ordination methods, redundancy analysis (RDA), might be appropriate [39]. Redundancy analysis is appropriate in situations where narrow environmental gradients have been sampled, which indicates that the most taxa within the calibration set respond to changes in the environment in a linear fashion [38].

Environmental data included (Table 1, [27]): mean January, mean July, annual and water temperatures, altitude, vegetation, water depth, Secchi depth, conduc- tivity, $\mathrm{pH}$, dissolved organic carbon (DOC), chloride $\left(\mathrm{Cl}^{-}\right)$, sulfate $\left(\mathrm{SO}_{4}^{2-}\right)$, bromide $\left(\mathrm{Br}^{-}\right)$, nitrite $\left(\mathrm{NO}_{2}^{-}\right)$, ammonium $\left(\mathrm{NH}_{4}^{+}\right)$, total phosphorus $(\mathrm{P})$, carbonate $\left(\mathrm{HCO}_{3}^{-}\right)$, some metals $\mathrm{Al}^{3+}, \mathrm{Ba}^{2+}, \mathrm{Ca}^{2+}, \mathrm{Fe}_{\text {tot }}, \mathrm{Mg}^{2+}$, and $\mathrm{Na}^{+}$. Some of the variables were log transformed to reach a normal distribution. Conductivity, $\mathrm{Cl}^{-}, \mathrm{SO}_{4}^{2-}$, $\mathrm{HCO}_{3}^{-}, \mathrm{Al}^{3+}$, and $\mathrm{Na}^{+}$were $\ln (x+1)$ transformed, lake depth, $\mathrm{NO}_{2}^{-}$, and $\mathrm{P}$ were $\log 10$ transformed. Ordinations were performed using the program CANOCO 4.5 [40].

Variance inflation factors (VIF) were used to identify the intercorrelated variables. Environmental variables with VIFs greater than eight were eliminated, one at a time, beginning with the variable that had the highest VIF until all VIFs were below eight. The minimum number of environmental variables that explained significant $(p \leq 0.05)$ variations in the chironomid data was then determined by forward selection. Statistical significance of forward-selected variables and the RDA axes was estimated using the Monte Carlo test (999 unrestricted permutations, $p \leq 0.05$ ).

Chironomid communities diversity and evenness were estimated using Shannon index $(\mathrm{H})$ [41] and Pielou index (I) [42]. The effective number of occurrences of chironomid species were estimated by the index N 2 [43]. 


\section{RESULTS}

Seventy-five chironomid taxa were identified in the investigated lakes. Forty taxa belonged to Chironominae (25 Chironomini, 15 Tanytarsini), 33 taxa to Orthocladiinae, and two to Tanypodinae (Procladius and Tanypodinae unidef.).

Forty-seven taxa had a relative abundance of $2 \%$ in at least one lake and were included into the calibration data set (Fig. 3). The complete list of central Yakutian chironomid taxa is published at the Russian Chironomid homepage (http://www.biosoil.ru/tendipes/cata $\log . h t m)$.

None of the taxa occurred in all the lakes. Most abundant were Chironomus anthracinus type, Psectrocladius sordidellus type, Paratanytarsus penicillatus, Cricotopus sp. E, Dicrotendipes, Tanytarsus lugens type. (Fig. 3). Several taxa have been found for the first time in northeastern Russia: Nanocladius $B$ (rectinervus?), Glyptotendipes severini, Pogonocladius, Propsilocerus, Psectrocladius barbimanus, Stenochironomus, Trissocladius (Fig. 1).
Variations of the indices describing qualitative characteristics of chironomid communities are presented in Table 2. In all the lakes chironomid communities are quite rich and diverse with relatively stable structure, except for lake 1733, where all the indices are much lower than in other lakes $(\mathrm{N}=12 ; \mathrm{N} 2=2.29 ; \mathrm{H}=2.05$; $\mathrm{I}=0.57)$. This is the only hypertrophic lake in the set. The chironomid community of this lake is overdominated by Chironomus anthracinus type. (64.79\%).

Redundancy analysis using all environmental variables (square root transformation of species, forward selection of environmental variables, 999 unrestricted permutations of Monte Carlo test, $p \leq 0.05$ ) provided eigenvalues 0.143 for axis 1 and 0.105 for axis 2 and explained $58.4 \%$ of the relationships between chironomid taxa and measured environmental variables. Subset of 13 most important variables includes: $T_{\mathrm{July}}, T_{\mathrm{Jan}}, T_{\mathrm{ann}}$, Secchi, vegetation zone, depth, conductivity, $\mathrm{O}_{2}, \mathrm{Cl}^{-}$, , $\mathrm{Al}^{3+}, \mathrm{Mg}^{2+}, \mathrm{Na}^{+}$, but $T_{\text {July }}, T_{\text {Jan }}, T_{\text {ann }}$ and conductivity, $\mathrm{Mg}^{2+}, \mathrm{Na}^{+}, \mathrm{Cl}^{-}, \mathrm{Sr}^{2+}$ have high variance inflation factors (VIF above 8) showing high level of intercorrelations. These variables were eliminated one by one until VIFs became below 8 .

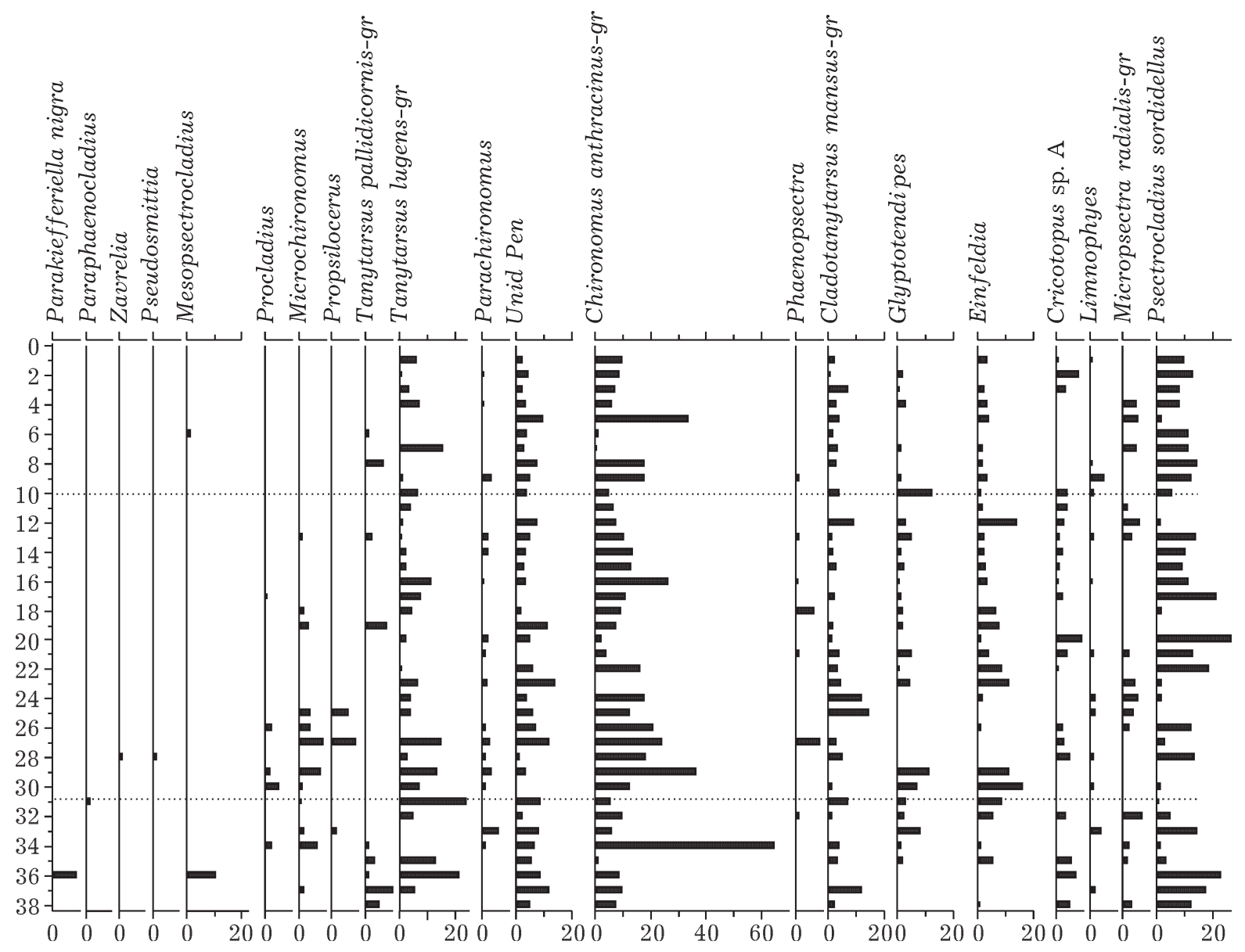

Fig. 3. A stratigraphic diagram illustrating quantitative distribution of main chironomid taxa in central Yakutian lakes. Data are sorted by mean July temperature. 
Redundancy analysis identified five environmental variables that have no correlation to each other and have a significant relationship $(p \leq 0.05)$ with the distribution of chironomids in the investigated lakes. These five variables are $\mathrm{Mg}^{2+}, \mathrm{Al}^{3+}, T_{\text {July }}$, Secchi depth, $\mathrm{O}_{2}$. Using these variables as the sole environmental variables, RDA provided eigenvalues 0.113 for axis 1 and 0.088 for axis 2 , which constitute $90.4 \%$ and $94.6 \%$ of the eigenvalues of axes 1 and 2 obtained from 13 most significant variables. Thus, the explanatory power of the five remaining environmental variables was not strongly reduced by eliminating the correlated variables. $\mathrm{Al}^{3+}$ correlates positively with axis $1 ; \mathrm{Mg}^{2+}$ and $T_{\text {July }}$ significantly correlate with axis 2 ; Secchi depth correlates negatively with axis 1 , and $\mathrm{O}_{2}$ correlates negatively with axes 1 and 2 (Table 3 ).

Sites with high scores of axis 1 (Fig. 4) are alkaline, good oxygenated lakes, with very high conductivity (up to $2980 \mu \mathrm{S} / \mathrm{cm}$ ), high concentrations of major cations and elevated DOC content $(30.52 \mathrm{mg} / \mathrm{l})$. These lakes are dominated by Chironomus anthracinus type (max abundance $64.79 \%$ ), Tanytarsus lugens type (max $21.43 \%$ ), Psectrocladius sordidellus type (max $23.21 \%$ ), relatively frequent are larvae of the genus Microchironomus (max 9\%) and only in the lakes of this group high densities of Mesopsectrocladius (10.71\%), Parakiefferiella nigra $(8.93 \%)$ and Propsilocerus jacuticus $(9.09 \%)$ were observed. Indices of biodiversity in this group of lakes are quite high $(\mathrm{H}=3.0, \mathrm{~N} 2=6.3)$ as in all central Yakutian lakes. But evenness (I) reflecting the structural stability of chironomid communities averages 0.8 . It goes down to 0.57 only in lake 1733 , where the community is strongly dominated by Chironomus. All the lakes of this group mainly surrounded by pastures are situated in Ust'-Aldan Ulus near Yakutsk. The climatic conditions are rather extreme: $T_{\mathrm{Jan}}=-42.3^{\circ} \mathrm{C}$; $T_{\text {July }}=+18.06^{\circ} \mathrm{C} ; T_{\text {ann }}=-9.77^{\circ} \mathrm{C}$.

Sites with high scores of axis 2 are lakes of forest zone. Apart from lake 1730, they all are situated near Vilyuisk, with the "milder" (in comparison with previous sites $)$ climatic conditions $\left(T_{\mathrm{Jan}}=-38.5^{\circ} \mathrm{C}, T_{\text {July }}=\right.$ $+17.2{ }^{\circ} \mathrm{C}, T_{\text {ann }}=-8.57{ }^{\circ} \mathrm{C}$ ). The lakes are characterized by low conductivity and, consequently, by low concentrations of main cations and anions and lower concentration of DOC $(14 \mathrm{mg} / \mathrm{l})$. There are no prominent species dominants, like Chironomus in the previous

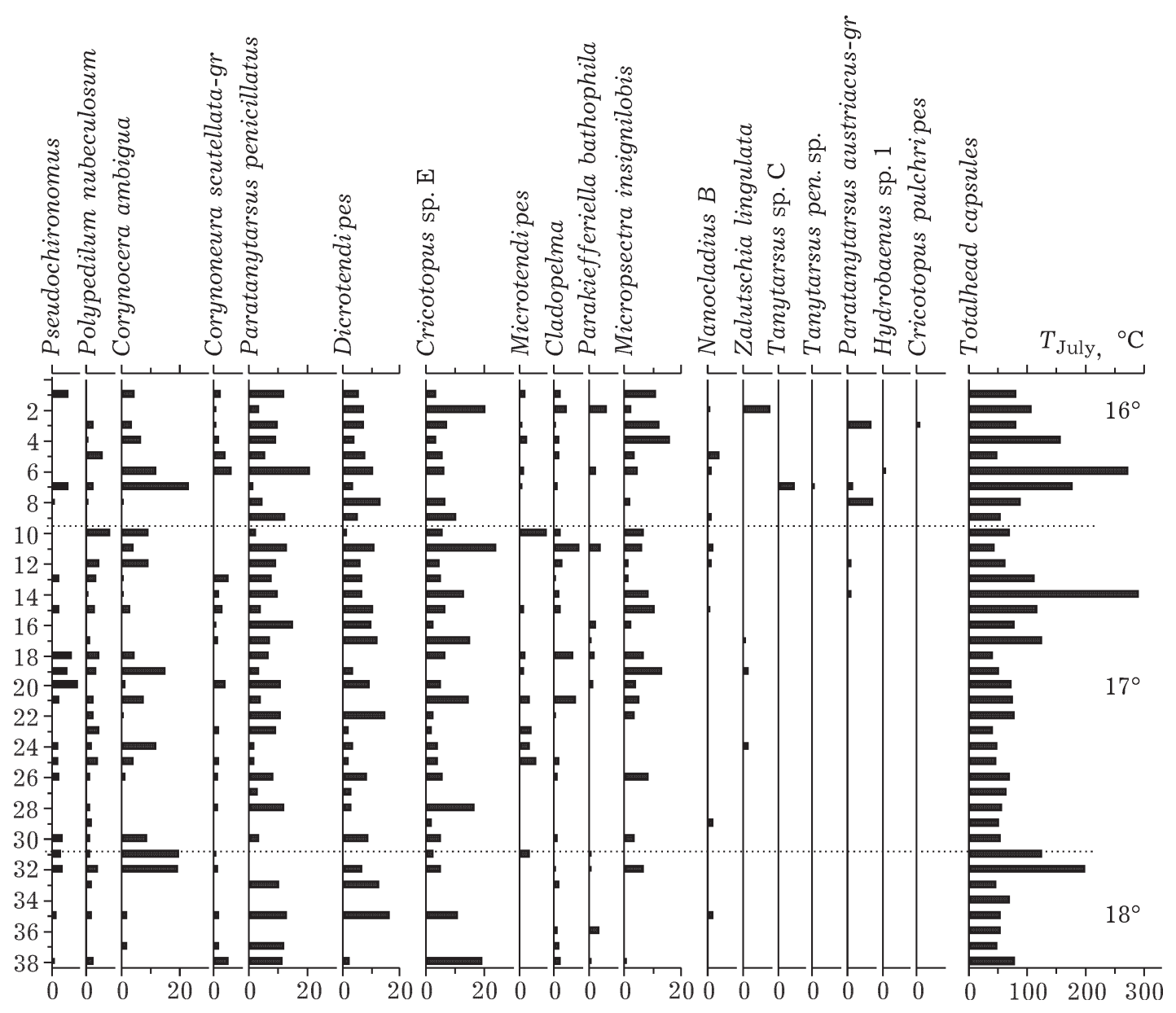

Fig. 3. (Contd.) 
Table 2. Characteristics of Chironomid fauna of central Yakutian lakes

\begin{tabular}{lrrrrrr}
\hline \multicolumn{1}{c}{ Variable } & Mean & Median & Min & Max & SD & Skew \\
\hline N taxa per lake & 19.95 & 20.00 & 12.00 & 32 & 4.4531 & 0.375 \\
N2 & 10.95 & 10.96 & 5.28 & 16.078 & 2.7825 & -0.014 \\
H (Shannon Index) & 3.76 & 3.76 & 2.94 & 4.3198 & 0.3311 & -0.493 \\
I (evenness) & 0.88 & 0.89 & 0.80 & 0.9632 & 0.0455 & -0.51 \\
\hline
\end{tabular}

group of lakes. The group of the most frequent taxa consists of Tanytarsus lugens type (max abundance $24.0 \%)$, Corynocera ambigua (max $20.0 \%)$, Chironomus anthracinus type ( $\max 18.0 \%)$, Cladotanytarsus type mancus ( $\max 14.89 \%$ ), quite abundant are Einfeldia (max 8.8\%), Microtendipes ( $\max 6.38 \%$ ), and Pseudochironomus (6.15\%). Biodiversity indices are higher in this group of lakes with average $\mathrm{H}=3.8$, and $\mathrm{N} 2=11.0$, absence of dominant taxa is confirmed by higher evenness indices, averaging out at 0.9.

Sites with low scores of axes 1 and 2 are very shallow lakes of pasture zone from the Vilyuisk region, with very high oxygen concentration, good (in comparison to other sites) transparency (more than $1 \mathrm{~m}$ ), and, as compared with lakes of the previous group, somewhat higher conductivity $(284 \mu \mathrm{S} / \mathrm{cm})$ and concentrations of main anions and cations and DOC $(18.65 \mathrm{mg} / \mathrm{l})$. Chironomid communities of this group of lakes are diverse $(\mathrm{H}=3.9, \mathrm{~N} 2=11.7)$ have even structure $(\mathrm{I}=0.89)$ without any dominant taxa. The most frequent taxa are of Cricotopus type E (max 24.4\%), Paratanytarsus penicillatus type $(\max 21.7 \%)$, Psectrocladius sordidellus type ( $\max 18.75 \%)$, Chironomus anthracinus gr. ( $\max 16.3 \%)$, Dicrotendipes $(\max 15.0 \%)$, Micropsectra insignilobis type (max 12.2\%), Corynocera ambigua (max 12.04\%). Other phytophylic taxa like Endochironomus, several Cricotopus species Glyptotendipes and various Tanytarsini taxa are also quite abundant.

\section{DISCUSSION}

The literature data on Yakutian chironomids indicate that the fauna is quite rich and diverse [44-56].

Table 3. Weighted correlations of environmental variables and RDA ordination axes

\begin{tabular}{lcc}
\hline \multirow{2}{*}{ Environmental variable } & \multicolumn{2}{c}{ RDA } \\
\cline { 2 - 3 } & Env Ax 1 & Env Ax 2 \\
\hline$T_{\text {July }}$ & 0.1959 & 0.6458 \\
Secchi & -0.5061 & 0.2428 \\
$\mathrm{O}_{2}$ & -0.4780 & -0.2195 \\
$\mathrm{Al}$ & 0.6720 & -0.3127 \\
$\mathrm{Mg}$ & 0.0682 & 0.9668 \\
\hline
\end{tabular}

Some earlier surveys have confirmed similarities between chironomid fauna of Yakutia and the chironomid faunas of the other parts of Siberia and Far East [50, 52, $53,56]$. In early studies chironomids have been taken into account mainly as part of programs on estimation of productivity of benthic communities as a food source for fishes or studies of anthropogenic load on freshwater ecosystems. Identification was not made further than genus or larval form (f.l.) level, and complete faunistic lists are not presented. The only exception is the study of chironomids in the Ust'-Lena reserve [56] which revealed 125 species identified as a rule by imago. Larvae were found only for 12 species. Information on species ecology includes the type of the waterbody where the larvae occur (lake-pool-brook) and the character of habitat (sandy bottom-muds-algal mass).

Study of the distribution of chironomids in a transect of 31 lakes spanning tree line near the lower Lena mouth in north-central Siberia (northern Yakutia) was the first attempt to quantify the relationship between chironomids and climate at tree line in Russia [57], as part of a larger project aiming at reconstructing past movements of the circumpolar tree line. Chironomids in the lower Lena transect respond to the productivity of lakes in the most pronounced way. No significant relationship between chironomid distribution and surface water temperature was observed. This was partly due to the direct and indirect effect of sampling of a relatively small number of lakes. The lakes sampled in each vegetation zone were in proximity to one another and, as a result, did not span a broad environmental gradient. If a larger number of lakes were incorporated in the calibration set, a broader environmental gradient would be sampled and the influence of synoptic scale effects such as climate would be more apparent.

We did not find any significant dependence between water temperature and composition of chironomid communities either. Mean July temperature, on the contrary, appeared to be among the most important factors driving chironomid distribution $(5.4 \%$ of explained variance). Mean January and annual temperatures appeared also to be important, but the three parameters were strongly intercorrelated (VIF $T_{\text {Jan }}=141, T_{\text {ann }}=89$, $T_{\text {July }}=21$ ), so $T_{\text {July }}$ was left in our analysis as having the lowest inflation factor.

The set of our data on lakes spans a broader geographical area than the set of lakes in the study of 
(a)
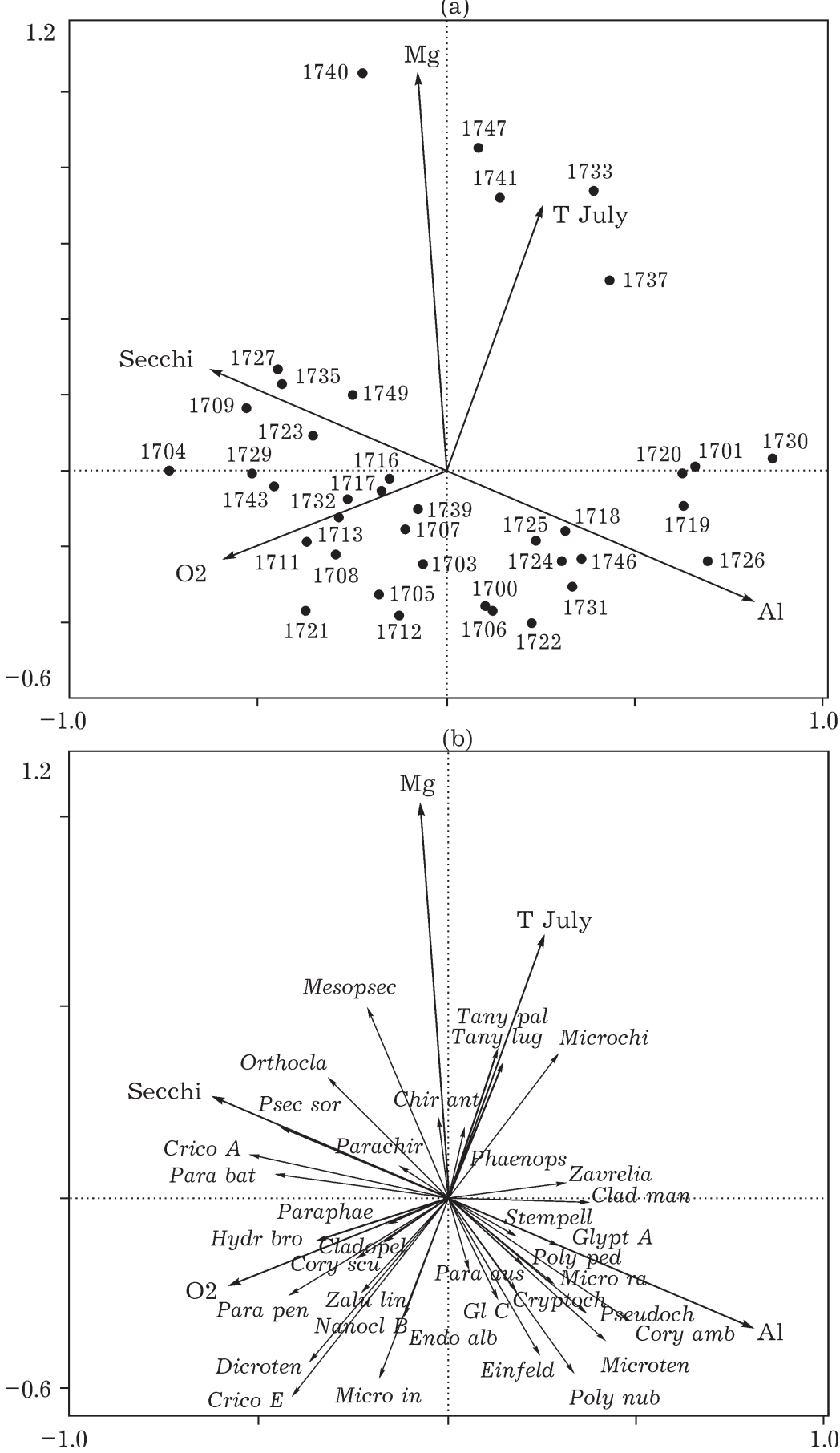

Fig. 4. RDA biplots illustrating the relationship between the most significant ecological factors and (a) chironomid communities of the investigated lakes and (b) most frequent chironomid taxa.

Porinchu and Cwynar [57], but the gradient of the most important ecological parameter, mean July temperature, was still too narrow to develop a chironomidbased temperature model. Other chemical and physical parameters of the investigated lakes vary significantly (Table 1): i.e. $14.6{ }^{\circ} \mathrm{C}$ (for comparison, in the Lena delta data set $8.5^{\circ} \mathrm{C}$, in the Norwegian data set $12.4^{\circ} \mathrm{C}[20]$ ), water depth $=16.4 \mathrm{~m}$, Cond $=2910 \mu \mathrm{S} / \mathrm{cm}$, etc.
Lake productivity did not appear to play any significant role in influencing the composition of the chironomid assemblages, although chironomids are known to be sensitive to the availability of fine organic matter in water and sediments $[58,59]$. Most probably, it was a consequence of generally low concentrations of nutrients in the investigated lakes. In our data set most of the lakes can be classified as oligothrophic [60]. Our analy- 
sis has shown that the physicochemical characteristics of the lakes and a climate-induced moisture deficit are the main variables controlling the distribution of chironomids. The lakes suffer from a negative water balance typical of central Yakutia. This is evident from exceptionally high concentrations of major ions, electrical conductivity as well as from the the high $\mathrm{Na} / \mathrm{Cl}$ ratios (for details see [27]). Among the most significant cations are $\mathrm{Mg}^{2+}(8.4 \%$ e.v. $)$ and $\mathrm{Al}^{3+}$ (7.3\% e.v.). Although $\mathrm{Al}^{3+}$ concentrations in all the lakes were generally low, statistical analysis has shown that it is among the most important variables that control the distribution of chironomids. This can be explained by two main reasons. On the one hand average concentration of $\mathrm{Al}$ in the lakes from the Yakutsk region was very low (20.7 $\pm 2.0 \mathrm{~g} / \mathrm{l})$. In 10 of 13 lakes it was below the analytically detectable minimum $(20.0 \mathrm{~g} / 1)$. In the Vilyuisk region concentrations of Al were slightly higher (31.6 $\pm 15.9 \mathrm{~g} / \mathrm{l})$. Although the coefficient of correlation "region-Al concentration" was as small as 0.3 , to a certain degree it can be attributed to geographical location of the lakes (Fig. 4). On the other hand, the importance of $\mathrm{Al}$ can reflect the complex limnological processes taking place in the thermokarst Yakutian lakes, as biogeochemical cycle of aluminium is closely connected with cycles of silicon and phosphorus [61-63]. Both also make significant indirect contributions to the cycling of aluminium in the lithosphere, for example, phosphates are significant sinks for aluminium [64, 65], and the association of aluminium with silica in frustules of diatoms [66, 67], is a key component of the sedimentation of aluminium. It is proved that for both silicon-requiring (diatoms) and non-silicon-requiring (green algae) organisms silicon increases the biological availability of inorganic phosphate in the presence of aluminium [68]. The revealed correlation between Al concentrations and distribution of chironomids is a complex phenomenon and demands further investigation.

Most of the lakes in our data set are shallow and relatively small, but transparency of the lakes varies considerably (Table 1). On the average, Secchi depths were approximately half of the maximum water depths. For the majority of the lakes, poor transparency was likely to be a result of wind-induced resuspension of the sediments. In some exceptional cases (e.g. lakes 1733, 1741), low Secchi depths were caused by enhanced nutrient concentrations. Transparency of the water column does not have a direct effect on chironomid biology. But indirectly, as integrative parameter resulting from many intercorrelated physical, chemical and functional characteristics of the lake ecosystems such as quality and mechanical composition of sediments (sand, clay, rock etc.), availability of organic matter and ionic composition favorable or not favorable for phytoand zooplankton populations, density of macrophytes and macrovertebrate populations, as well as the state of the catchments area, it influences on metabolism of chironomid and consequently on their distribution.

\section{CONCLUSION}

The investigation has demonstrated that chironomid fauna of central Yakutian lakes is abundant and diverse. The main factors influencing chironomid distribution are climate-dependent parameters: $T_{\text {July }}$ and concentrations of major cations related to negative water balance in the region. The results obtained encourage further works on making a regional chironomid-based temperature model appropriate for the Arctic regions of Russia as a whole and Yakutia in particular.

\section{ACKNOWLEDGEMENTS}

The authors would like to thank all participants of the expeditions of the summers of 2003 and 2004 in central Yakutia, PhD student of YSU Marta Ksenofontova. LN is very grateful to Mr. Steven Brooks (NHM, London) for help in correct chironomid identification and Dr. Wolfgang Riss (Uni, Muenster) for advice in statistical and ecological analyses of the data. The authors are also grateful to anonymous reviewers for valuable comments and recommendations. The project is supported by Alexander von Humboldt Foundation.

\section{REFERENCES}

1. D. M. Rosenberg and V. H. Resh, in Freshwater Biomonitoring and Benthic Macroinvertebrates (Chapmen \& Hall, New York, 1993), pp. 1-9.

2. C. Lindegaard, in The Chironomidae - Biology and Ecology of Non-Biting Midges (Chapman \& Hall, London, 1995), pp. 385-404.

3. I. R. Walker, in Tracking environmental change using lake sediments, Vol. 4: Zoological Indicators (Kluwer, 2001), pp. 43-66.

4. L. B. Nazarova and S. J. Brooks, Euroas. Entomol. J. 3 (4), 300 ( 2004).

5. S. J. Brooks, Quat. Sci. Rev. 25, 1894 (2006).

6. J. P. Smol, A. P. Wolfe, H. J. B. Birks, M. S. V. Douglas, V. J. Jones, A. Korhola, R. Pienitz, K. Ruhland, S. Sorvari, D. Antoniades, S. J. Brooks, M.-A. Fallu, M. Hughes, B. Keatley, T. Laing, N. Michelutti, L. Nazarova, M. Nyman, A. M. Paterson, B. Perren, R. Quinlan, M. Rautio, E. Saulnier-Talbot, S. Siitonen, N. Solovieva, and J. Weckstrom, Proceedings of the National Academy of Sciences of the United States of America 102, 4397 (2005).

7. I. R. Walker and R.W. Mathewes, Quat. Res. 27, 89 (1987).

8. B. G. Wamer and B. J. Hann, Quat. Res. 28, 427 (1987).

9. W. F. Warwick, J. Paleolim. 2, 15 (1989).

10. B. J. Hann, B. G. Wamer, and W. F. Warwick, Can. J. Fish. Aquat. Sci. 49, 1274 (1992).

11. I. R. Walker, J. P. Smol, D. R Engstrom, and H. J. B. Birks, Can. J. Fish. Aquat. Sci., 1992, 49, 1276-1280.

12. A. F. Letter, H. J. B. Birks, W. Hofmann, and A. Marchetto, J. Paleolim. 18, 395 (1997). 
13. S. J. Brooks and H. J. B. Birks, J. Quat. Sci. 15, 759 (2000).

14. R. W. Battarbee, Quat. Sci. Rev. 19, 107 (2000).

15. J. Massaferro and S. J. Brooks, J. Quat. Sci. 17, 101 (2002).

16. N. Solovieva, V. J. Jones, L. Nazarova, S. J. Brooks, H. J. B. Birks, J.-A. Grytnes, P. G. Appleby, T. Kauppila, B. Kondratenok, L. Renberg, and V. Ponomarev, J. Paleolim. 33, 463 (2005).

17. I. R. Walker, A. J. Levesque, L. C. Cwynar, and A. E. Letter, J. Paleolim. 18, 165 (1997).

18. H. Olander, A.Korhola, H.J.B. Birks, and T. Blom, The Holocene 9, 279 (1999).

19. I. Larocque, R. I. Hall, and E.Grahn, J. Paleolim. 26, 307 (2001).

20. S. J. Brooks and H. J. B. Birks, Quat. Sci. Rev. 20, 1723 (2001).

21. A. L. Takhtadzhan, Floristic Areas of the World (Nauka, Leningrad, 1978) [in Russian].

22. Diversity of Yakutian Flora (Izd. SO RAN, Novosibirsk, 2005) [in Russian].

23. M. K. Gavrilova, Climate of Central Yakutia (Inst. Merzlotovedeniya, Akad. Nauk SSSR, Yakutsk, 1973) [in Russian].

24. M. Ksenofontova, T. Kumke, L. Pestryakova, and H.-W. Hubberten, in Deutsche Gesellschaft fuer Limnologie Tagungsbericht 2004 (Berlin, 2005), pp. 141-145.

25. A.V. Pavlov, Perm. Perigl. Proc. 5, 101 (1994).

26. L. Agafonov, H. Strunk, and T. Nuber, Palaeogeography, Palaeoclimatology, Palaeoecology 209, 183 (2004).

27. T. Kumke, M. Ksenofontova, L. Pestryakova, L. Nazarova, and H.-W. Hubberten, Aqu. Sci. 66 (1), 40 (2007).

28. L. Nazarova, T. Kumke, L. Pestrjakova, and H.-W. Hubberten, Chironomus 18, 25 (2005).

29. M. New, M. Hulme, and P. Jones, J. Clim. 13, 2217 (2000).

30. Chironomidae of the Holarctic Region. Keys and Diagnoses, Part 1: Larvae, Ed. by T. Wiederholm (Entomologica Scandinavica, Suppl. 19, 1983) .

31. D. R. Oliver and M. E. Roussel, The Genera of Larval Midges of Canada. Diptera: Chironomidae (Biosystematics Research Inst., Ottawa, Ontario, 1983).

32. E. A. Makarchenko and M. A. Makarchenko, in Key to Freshwater Invertebrates of Russia and Adjacent Lands, Vol. 4: Higher Insects. Diptera (Zoological Institute RAS, St. Petersburg, 1999), pp. 210-295, 670-857 [in Russian].

33. S. J. Brooks, P. G. Langdon, and O. Heiri, in QRA Technical Guide (London Quaternary Research Association, Cambridge, 2007), p. 10.

34. M. Rieradevall and S. J. Brooks, J. Paleolim. 25, 81 (2001).

35. H. J. B. Birks, in Statistical Modelling of Quaternary Science Data. Technical Guide 5 (Quaternary Research Association, Cambridge, 1995), pp. 161-254.

36. C. J. F. ter Braak and I. C. Prentice, Adv. Ecol. Res. 18, 271 (1988).

37. R. Pienitz, J. P. Smol, and H. J. B. Birks, J. Palaeolim. 13, 21 (1995).
38. C. J. F. ter Braak and P. F. M. Verdonschot, Aqu. Sci. 57, 255 (1995).

39. C. J. F. ter Braak, CANOCO 4.5 Reference Manual and CanoDraw for Windows. User's Guide: Software for Canonical Community Ordination (Version 4.5) (Microcomputer Power, Ithaca, NY, USA, 2002).

40. C. J. F. ter Braak and P. Smilauer, CANOCO v. 4.5 (Microcomputer Power, Ithaca, NY, USA, 2002).

41. F. P. Ryabov, A. K. Dyga, A. S. Kirilenko. V. I. Derkachenko, and R. S. Aleshkina, in Selfpurification and Bioindication of Polluted Waters (Nauka, Moscow, 1980), pp. 227-231 [in Russian].

42. E. C. Pielou, J. Theoret. Biol. 13, 131 (1966).

43. M. O. Hill, Ecology 54, 427 (1973).

44. I. I. Kiknadze, A. G. Istomina, L. I. Gunderina, T. A. Salova, K. G. Aimanova, and D. D. Savvinov, Cariofonds of Chironomids of Criolithozone of Yakutia: Triba Chironomini (Nauka, Novosibirsk, 1996) [in Russian].

45. F. E. Karantionis, F. N. Kirillov, and F. B. Mukhomed'yarov, in Fishes of the Middle Reaches of the Lena River, Proc. Inst. Biol. Yakutian Division of AS USSR (Yakutsk, 1956), Issue 2, pp. 3-144 [in Russian].

46. N. P. Vershinin, in Fauna of Fishes and Invertebrates of Vilyui Basin, Proc. Inst. Biol. Yakut. Division of AS USSR (Yakutsk, 1962), Issue 8, pp. 72-100 [in Russian].

47. N. P. Vershinin, in Fisheries of East Siberia (Krasnoyarsk, 1964), Vol. 8, pp. 251-256 [in Russian].

48. L.I. Sokolov, Voprosy Ikhtiologii, No. 6, 3 (1966).

49. E.A. Streletskaya, in Fisheries in the Lakes of Middle Kolyma (Yakutsk, 1972), pp. 115-139 [in Russian].

50. R. I. Ogay, in Biology of Vilyui Water Reservoir (Nauka, Siberian Branch, Novosibirsk, 1979), pp. 136-155 [in Russian].

51. R. I. Ogay, in Peculiarities of Ecology of Hydrobionts of Lower Lena (Yakutsk, 1987), pp. 61-72 [in Russian].

52. T. A. Salova, in Ecology of the Upper Amga River (Yakutsk, 1992), pp. 41-44 [in Russian].

53. T. A. Salova, in Ecology of the Middle Amga River (Yakutsk, 1993), pp. 44-48 [in Russian].

54. M. M. Tjaptirgjanov, T. M. Labutina, and V. A. Sokolova, in Ecology of Vilyui River Basin: Industrial Pollution (Yakutsk, 1992), pp. 64-70 [in Russian].

55. M. M.Tyaptirgyanov, T. A. Salova, V. A. Sokolova, and V. B. Kipriyanov, in Ecology of the Vilyui River (Yakutsk, 1993), pp. 127-142 [in Russian].

56. N. I. Zelentsov and A. I. Shilova, Biol. Vnutrennikh Vod, No. 1, 54 (1996).

57. D. F. Porinchu and L. C. Cwynar, Arc. Ant. Alp. Res. 32, 429 (2000).

58. O. E. Saether, Verh. Int. Ver. Limnol. 19, 3127 (1975).

59. O. A. Saether, P. Ashe, and D. E. Murray, in Contributions to a Manual of Palaearctic Diptera (with Special Reference to the Flies of Economic Importance) (Science Herald, Budapest, 2000), pp. 113-334.

60. R. A. Vollenweider and J. Kerekes, Eutrophication of Waters. Monitoring, Assessment and Control (Organization for Economic Co-Operation and Development (OECD), Paris, 1982). 
61. C. Exley, J. Inorg. Biochem. 69, 139 (1998).

62. V. Krivtsov, E. Bellinger, D. Sigee, and J. Corliss, Hydrol. Process. 14, 283 (2000).

63. C. Exley, J. Inorg. Biochem. 97, 1 (2003).

64. A. K. Darke and M. R. Walbridge, Biogeochemistry 51, $1(200)$.

65. J. Kopacek, K. U. UIrich, J. Hejzlar, J. Borovec, and E. Stuchlik, Water. Res. 2001, 35, 3783 (2001).
66. M. Gehien, L. Beck, G. Calas, A.M. Flank, J. Van Bennekorn, and J. E. E. Van Beusekom, Geochim. Cosmochim. Acta 66, 1601 (2002).

67. S. Dixit and P. Van Capellen, Geochim. Cosmochim. Acta 66, 2559 (2002).

68. C. Exley, A. Tollervey, G. Gray, S. Roberts, and J. D. Birchall, Proc. R. Soc. Lond. Ser. B. Biol. Sci. 253, 93 (1993). 